\title{
SEPTO-OPTIC DYSPLASIA PLUS
}

\section{Case report}

\author{
Emerson L. Gasparetto', Danny Warszawiak2, Arnolfo de Carvalho Neto ${ }^{3}$, \\ Paulo R. Benites Filho', Isac Bruck', Sérgio Antoniuk ${ }^{4}$
}

\begin{abstract}
Septo-optic dysplasia (SOD) is a syndrome composed by optic nerve and septum pellucidum dysgenesis. It has been classified into two subsets according to the embryogenesis and the neuropathological findings. Basically, the difference between these two groups is the presence or not of schizencephaly. The term SOD-Plus was recently proposed to describe SOD associated with cortical dysplasia. We report a 6month-old female patient who presented absent visual fixation since 4 months of age and delayed psychomotor development. Neurological examination demonstrated spastic left hemiparesis and ophtalmological evaluation revealed bilateral optic disc hypoplasia. The head computed tomography (CT) scan showed absence of the septum pellucidum, ventricular asymmetry and schizencephaly. The magnetic resonance imaging (MRI) showed complete absence of the septum pellucidum associated to optic nerves and chiasma atrophy, schizencephaly and cortical dysplasia. The patient underwent an evoked potential examination with flash stimulation, which revealed bilateral absence of cortical evoked potential. She was referred to visual stimulation and physiotherapy. We emphasize the neuroimaging of this syndrome and stress the importance of the clinical investigation for patients with septum pellucidum dysgenesis on MRI or CT scans.
\end{abstract}

KEY WORDS: magnetic resonance imaging, computed tomography, septo-optic dysplasia, septum pellucidum.

\section{Displasia septo-óptica plus: relato de caso}

RESUMO - A displasia septo-óptica (DSO) é síndrome composta por disgenesia do nervo óptico e do septo pelúcido, que pode ser dividida em dois subgrupos de acordo com sua embriogênese e achados neuropatológicos. A diferença básica entre estes dois grupos é a presença ou não de esquizencefalia. 0 termo DSO-plus foi proposto recentemente para descrever DSO associada a displasia cortical. Apresentamos uma paciente de 6 meses de idade com ausência de fixação visual desde os 4 meses e atraso do desenvolvimento psicomotor. 0 exame neurológico demonstrou hemiparesia espástica esquerda e a avaliação oftalmológica revelou hipoplasia do disco óptico bilateralmente. A tomografia computadorizada (TC) de crânio demonstrou ausência de septo pelúcido, assimetria ventricular e esquizencefalia. A ressonância magnética (RM) revelou ausência completa de septo pelúcido associada a atrofia dos nervos e quiasma ópticos, esquizencefalia e displasia cortical. A paciente foi submetida a exame de potencial evocado com estimulação por flashes que revelou ausência bilateral de potencial evocado cortical. Terapia paliativa foi iniciada com estimulação visual e fisioterapia. Os autores enfatizam os achados de neuro-imagem desta síndrome e a importância da investigação clínica e por métodos de imagem (TC e RM) em pacientes com disgenesia do septo pelúcido.

PALAVRAS-CHAVE: ressonância magnética, tomografia computadorizada, displasia septo-óptica, septo pelúcido.

Septo-optic dysplasia (SOD) is characterized by optic nerve hypoplasia along with dysgenesis of the septum pellucidum. The association of optic nerve hypoplasia and absence of the septum pellucidum was first described by Reeves in 1941', and De Morsier proved it in $1956^{2}$, who coined the term septo-optic dysplasia. Nearly two thirds of patients with SOD have hypothalamic-pituitary dysfunction and a

Discipline of Diagnostic Radiology, Department of Internal Medicine, University of Parana School of Medicine (ELG, DW, ACN, PRBF), and Section of Neuropediatrics, Hospital de Clínicas, University of Paraná (IB, SA), Curitiba PR, Brazil: ${ }^{1}$ Resident of the Diagnostic Radiology Section; ${ }^{2}$ Medical Student of the University of Paraná; ${ }^{3}$ Professor of the Discipline of Diagnostic Radiology; ${ }^{4}$ Professor of Neuropediatrics, Department of Pediatrics.

Received 14 November 2002, received in final form 12 February 2003. Accepted 1 March 2003. 
half has schizencephaly ${ }^{3}$. Barkovich et al ${ }^{4}$ classified SOD into two distinct anatomic subsets according to the embryogenesis and the neuropathological findings. One subset included patients with schizencephaly, normal-size ventricles, a remnant of the septum pellucidum and normal-appearing optic radiations. The second group of patients had no schizencephaly, but did exhibit complete absence of the septum pellucidum and diffuse white matter hypoplasia that resulted in ventriculomegaly. Miller et al. ${ }^{5}$ suggested the term SOD-Plus to describe SOD associated with malformation of cortical organization, which clinically manifests as global developmental delay and/or spastic motor deficits.

We present a case of SOD associated with cortical dysplasia, developmental delay, spastic motor deficit and imaging characteristics from both subsets of SOD.

\section{CASE}

A 6-month-old female patient was seen for absent visual fixation since two months before. The mother referred chicken-pox during the third month of pregnancy. Delivery was cesarean at 41 weeks of gestation, and the child wei-

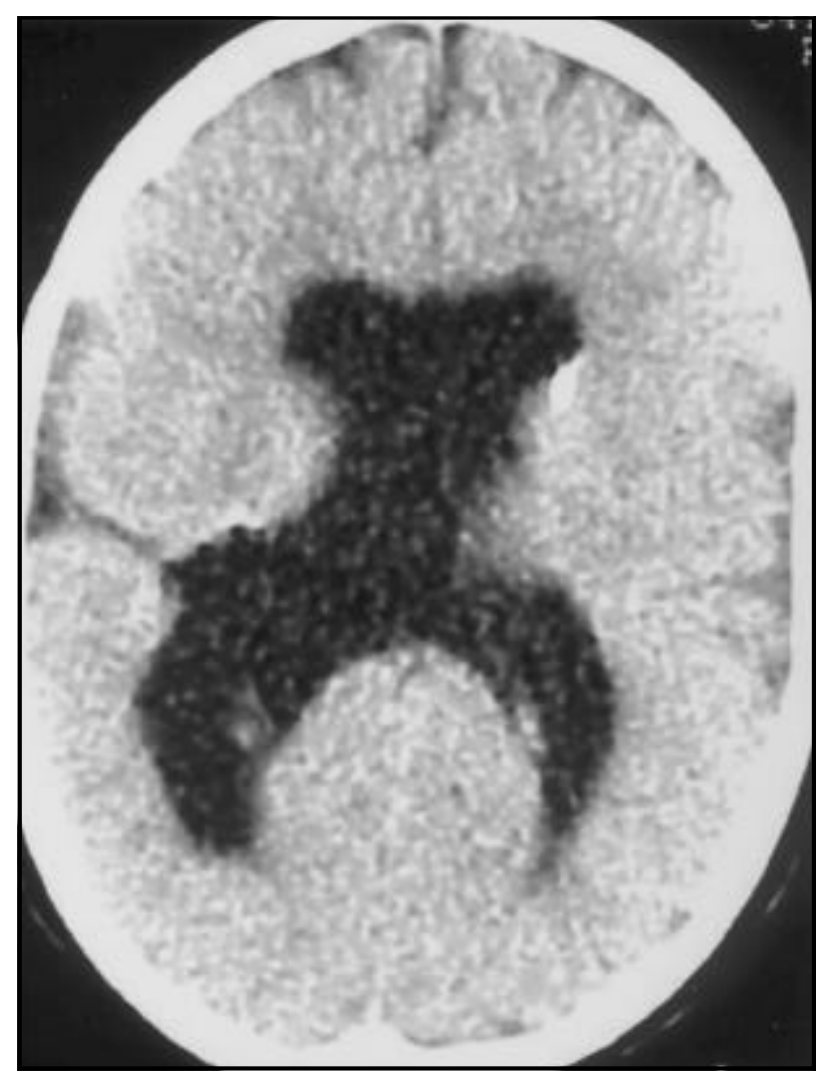

Fig 1. Axial CT scan revealing absence of the septum pellucidum, ventricular asymmetry, calcification spot in the wall of the frontal horn of the left lateral ventricle and schizencephaly with the cleft communicating the right lateral ventricle with the right temporoparietal convexity. ghted $3.355 \mathrm{~g}$ and had $36 \mathrm{~cm}$ of cephalic perimeter. There was a mild psychomotor development delay, as social smile was observed with 3 months of age and head sustentation with 3.5 months. Neurological examination showed spastic left hemiparesis and isochoric non-photoreactive pupils. Ophtalmological examination revealed bilateral optic disc hypoplasia. Endocrinological (seeking for hypopituitarism) and hepatic function tests were ruled but did not show any abnormalities. Genetic tests (for Hesx1 gene) were not performed in this case.

Computed tomography (CT) scan examination revealed absence of the septum pellucidum, optic nerves sheath at the anatomic position, ventricular asymmetry (the right ventricle larger than the left one), calcification spots in the wall of the frontal horn of the left lateral ventricle as well as in the trigon of the right lateral ventricle and schizencephaly with the cleft communicating the right lateral ventricle with the right temporo-parietal convexity (Fig 1). Magnetic resonance imaging (MRI) showed complete absence of the septum pellucidum associated to optic nerves and chiasma atrophy, and open-lips schizencephaly with dysplastic gray matter along the cortical surface. There was an area of cortical dysplasia in the right temporoparietal region, and we also observed periventricular whitematter atrophy in the left occipital and right occipito-parietal regions, with diffuse thinning of the corpus callosum (Figs 2,3,4).

Video-EEG waves were discretely slow to the age with no eptileptiform activity indicating unspecific generalized

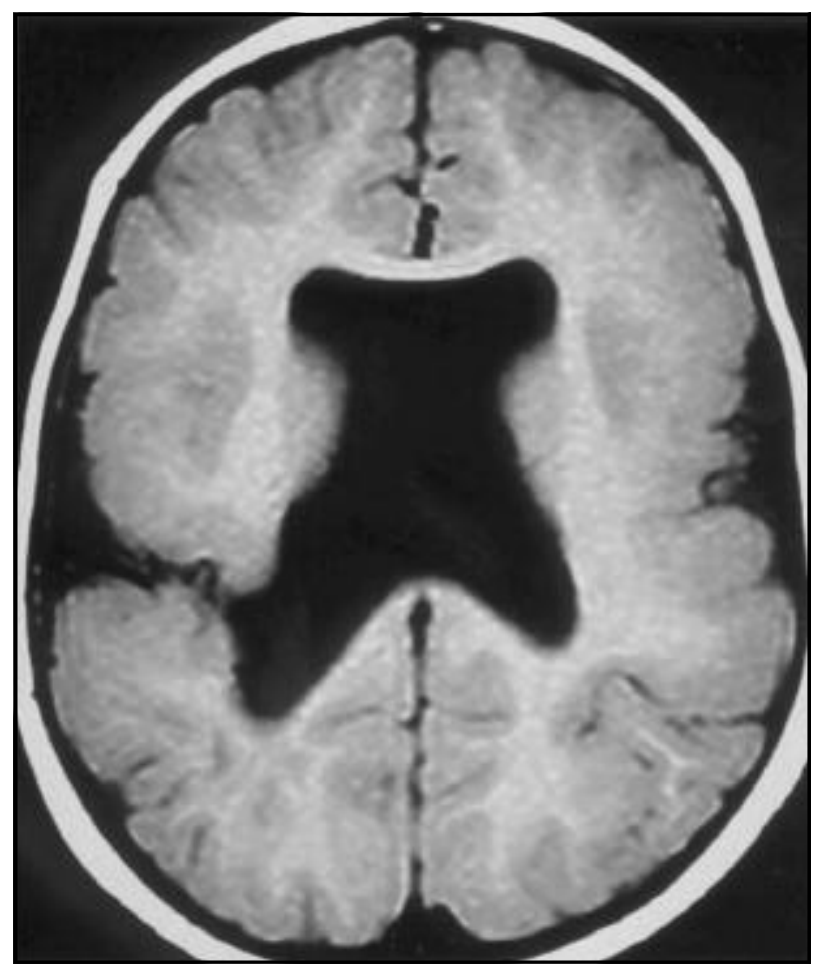

Fig 2. Axial T1 weighted MRI showing complete absence of the septum pellucidum and open-lips schizencephaly with dysplastic gray matter along the cortical surface. 


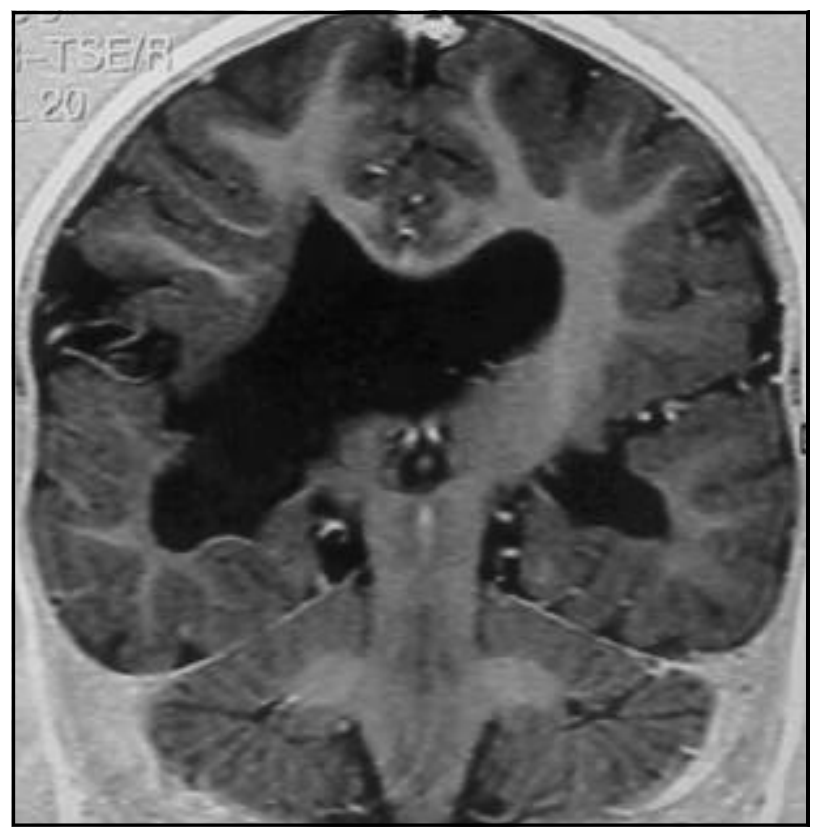

Fig 3. Coronal T1 weighted MRI demonstrating an area of cortical dysplasia at the right temporo-parietal region.

cerebral dysfunction. The patient underwent an evoked potential examination with flash stimulation in which cortical evoked potential was bilaterally absent. The patient was referred to physiotherapy and visual stimulation therapy.

\section{DISCUSSION}

Septo-optic dysplasia refers to a heterogeneous group of disorders that variably include optic nerve and/or optic chiasma hypoplasia and absence or dysgenesis of the septum pellucidum ${ }^{3-6}$. The clinical features may include variably partial pituitary insufficiency (from panhypopituitarism to isolated GH, ACTH or ADH insufficiency), various degrees of psychomotor retardation, mild to severe visual impairment, thermoregulatory disturbances, conjugated hyperbilirrubinemia and seizures ${ }^{3-8}$. Hence, the clinical presentation may be mild or extremely severe. Some features may not be evident but may be triggered by some exogenous agent, for instance hypoglycemic episodes triggered by ganciclovir treatment ${ }^{9}$. Therefore, either the symptoms are mild or severe, all features must be investigated since a recent study suggests that individuals with septo-optic dysplasia may be at risk of unexpected death at all ages ${ }^{10}$.

Regarding the imaging diagnosis of this entity, the most important feature is the second one as examination of the optic nerves is best performed by means of clinical evaluation since the imaging of the optic nerves and chiasm are normal in about half the patients with SOD ${ }^{11}$. Other imaging findings, such as schizencephaly, white matter hypoplasia, pituitary hypoplasia and cortical dysplasia may appear but they are not obligatory for defining the diagnosis of SOD. Since the absence of the septum pellucidum may be the only alteration on the neuroimaging of this patients ${ }^{11}$, differential diagnosis of this condition should be considered. Barkovich and Norman proposed an algorithm (Fig 5) ${ }^{11}$, which divides the patients with absence of the septum pellucidum into seven basic groups: SOD; schizencephaly; holoprosencephaly; corpus callosum agenesis; chronic severe hydrocephalus (aqueductal stenosis and Chiari II malformation); basilar encephaloceles; and porencephaly / hydranencephaly. Using this algorithm it is possible to confirm that the presence of small optic nerves and/or chiasm is not necessary to the correct diagnosis of SOD.

Barkovich et al. ${ }^{4}$ divided SOD into two different subsets according to the embryogenesis ${ }^{4}$. The main difference between the two types is the presence or not of schizencephaly, which is a congenital brain anomaly characterized by full-thickness clefts spanning the cerebral hemispheres, characterized by an infolding of gray matter along the cleft from the cortex to the ventricles, and a fusion of the cortical pia and ventricular ependyma within the cleft. Schi-

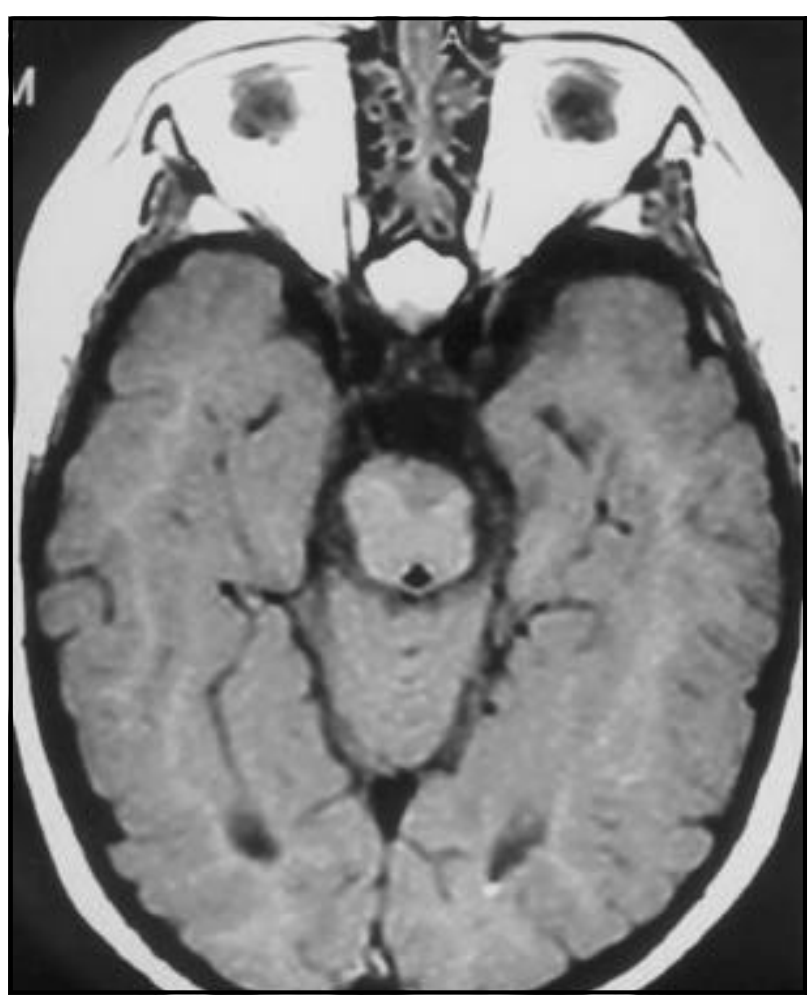

Fig 4. Axial T1 weighted MRI revealing optic nerves and chiasma atrophy. 


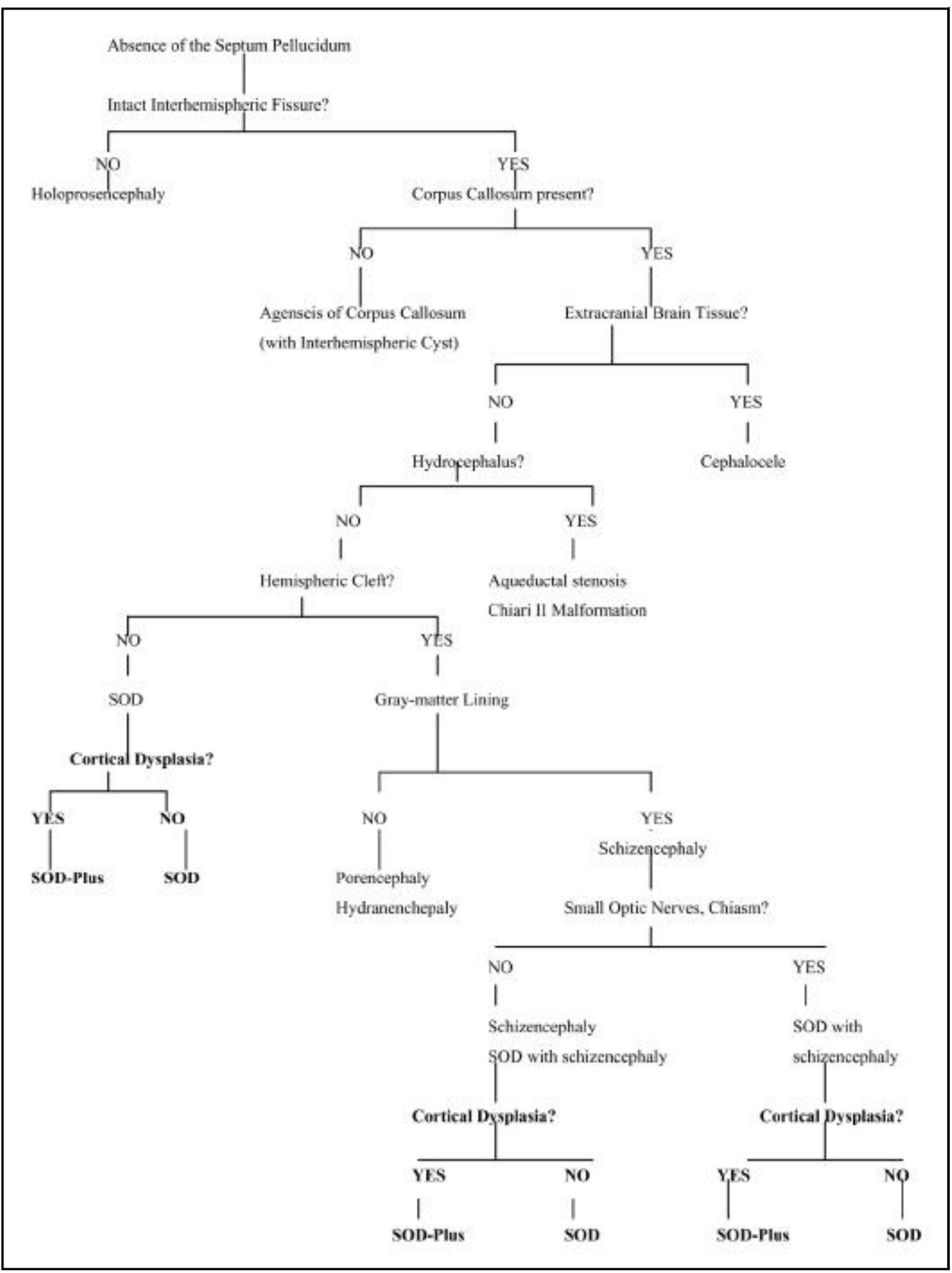

Fig 5. Algorithm to facilitate diagnosis of underlying brain anomaly in patients with absence of the septum pellucidum (Modified from Barlkovich et al. ${ }^{11}$ )

zencephaly is observed in about a half of the patients with $\mathrm{SOD}^{3}$ and both are associated with the absence of the septum pellucidum in $75-100 \%$ of the patients $^{12}$. Gray-matter heterotopias and gyral anomalies (polymicrogyria) are frequently found within and near to the cleft and they may be demonstrated on the MRI but not on the CT scans ${ }^{12}$. The division into these two subsets is neuroradiological and not used by many authors, however since the imaging aspects of the syndrome are discussed in this article, this classification is the one chosen by the authors.

The SOD type I is associated with schizencephaly. These patients have normal-size ventricles, a remnant of the septum pellucidum and normal-appearing optic radiations. The corpus callosum can also be focally thinned in these patients. Clinically they tend 
to present with seizures and/or visual symptoms. The embryological basis of this association have been proposed to be an insult (hypoperfusion or infection) to the brain during the late $7^{\text {th }}$ or $8^{\text {th }}$ week of gestation, when the optic nerve, germinal matrix, and septum are being formed ${ }^{4,12,13}$. Some factors such as maternal diabetes, licit or illicit drug abuse or cytomegalovirus infection have been implicated ${ }^{7}$. Diffuse calcifications associated with schizencephaly and absence of the septum pellucidum are often the result of in utero infection with cytomegalovirus. However, some cases are considered to have a mendelian autosomal recessive pattern of inheritance. The genetic factor was proposed due to five different heterozygous lack mutations in the homeobox gene Hesx 1 that are linked to either relatively mild pituitary hypoplasia or SOD ${ }^{14,15}$. In mice, the homologue gene of human Hesx 1 was proved to be an important role in forebrain, midline and pituitary development. The absence of this gene, in mice, result in absent or hypoplastic optic vesicles, pituitary abnormalities, reduction in prosencephalic tissue and abnormal morphogenesis of the corpus callosum and septum pellucidum ${ }^{15}$. In human beings homozygous mutations in the Hesx 1 gene have been identified in two siblings with optic nerve hipoplasia, absence of the corpus callosum and hipoplasia of the pituitary gland $^{16}$. Another possible mutation, which has not yet been described in humans, is in the axon guidance molecule netrin-1 and its receptor DCC (expressed on retinal ganglion cells), who interact in the developing optic disc to direct axonal growth into the optic stalk ${ }^{15}$. The absence of netrin-1 or DCC, in mice, result in optic nerve hipoplasia, ectopic axonal growth within the retina, hypothalamic changes and absence of the corpus callosum ${ }^{15}$. In addition, another etiology was recently proposed referring to a mitochondrial cytochrome $b$ heteroplasmic mutation (T14849C), resulting in SOD, retinitis pigmentosa, exercise intolerance, hypertrophic cardiomyopathy and rabdomyolisis ${ }^{17}$.

Although genetic tests were not performed in the reported case the presence of the calcification spots in the walls of the ventricles could lead to an infectious etiology. The history of chicken-pox during pregnancy would not be implicated since it has occurred in the third trimester and the insult that resulted this condition must have occurred in the first trimester. The SOD type II is not related to schizencephaly but it is associated with complete absence of the septum, white-matter hypoplasia, including optic radiations and diffuse callosal thinning, resulting in ventriculomegaly. On the presentation these patients have symptoms of hypothalamic-pituitary dysfunction. The cause of this abnormality is considered to be a mild lobar holoprosencephaly ${ }^{4}$.

Our patient contradicts the classification described above, as she shows characteristics of both subsets. The patient presented with schizencephaly and visual symptoms, which are characteristics of SOD type I, but she also presented white matter hypoplasia (diffuse thinning of the corpus callosum), ventricular dilatation and complete absence of the septum pellucidum, which are described as SOD type II findings. A focal narrowing of the corpus callosum, whose location is correlated with the cleft, may be found in patients with schizencephaly ${ }^{4,6}$, but diffuse callosal thinning, as observed in this case, was only seen in patients without schizencephaly ${ }^{4}$.

A third type of SOD is associated to cortical dysplasia. This association was described by Sener ${ }^{18}$ and Miller et al. ${ }^{5}$ who named this association as SODPlus. This abnormality can also be distinguished from isolated SOD by the presence of significant global development delay and spastic motor deficits ${ }^{5}$.

Focal cortical dysplasia is among the most commonly abnormalities associated with schizencepahaly ${ }^{19,20}$, and a common pathogenetic origin was proposed for this two entities, because schizencephaly may be an extreme form of polymicrogiria ${ }^{21,22}$. The clinical presentation of schizencephaly depends on the amount of brain tissue involved ${ }^{12,19,20-22}$. Patients with small unilateral schizencephalies generally have a good prognosis for the development ${ }^{19,21,22}$, with only mild development delay and/or motor deficits. This is significantly different from what was observed in our patient, who presented with global psychomotor development delay and severe motor deficit associated to cortical dysplasia and a relative small cleft.

This report shows some pitfalls in classifying SOD, demonstrating the importance of a detailed examination, especially through brain MRI and cortical evoked potential, in children with developmental delay and absence of the septum pellucidum to determine associated malformations.

\section{REFERENCES}

1. Reeves DL. Congenital absence of the septum pellucidum: case diagnosed encephalographically and associated with congenital amaurosis. Bull Johns Hopkins Hosp 1941;69:61-71.

2. De Morsier G. Etudes sur les dysraphies cranio-encephaliques. III. Agenesie du septum lucidum avec malformation du tractus optiqe: la dysplasie septooptique. Schweiz Arch Neurol Psychiatr 1956;77:267-292.

3. Lau KY, Tam W, Lam PK, Wood BP. Radiological cases of the month. Septo-optic dysplasia (De Morsier syndrome). Am J Dis Child 1993 Jan;147:71-72. 
4. Barkovich AJ, Fram EK, Norman D. Septo-optic dysplaisa: MR imaging. Radiology 1989;171:189-192.

5. Miller SP, Shevell MI, Patenaude Y, et al. Septo-optic dysplasia plus: spectrum of malformations of cortical development. Neurology 2000;54:1701-1703.

6. Hoyt WF, Kaplan SL, Grumbach MM, Glaser JS. Septo-optic dysplasia and pituitary dwarfism. Lancet 1970;1:893-894.

7. Orrico A, Galli L, Zappella M, et al. Septo-optic dysplasia with digital anomalies associated wiht maternal multidrug abuse during pregnancy. Eur J Neurol 2002;9:679-682.

8. Greco F, Finocchiaro M, Polizzi A, Caruso M. Early-onset of septo-optic dysplasia. A case report with follow-up. Minerva Pediatr 2002;54:57-62.

9. Fischler B, Casswall TH, Malmborg P, Nemeth A. Ganciclovir treatment in infants with cytomegalovirus infection and cholestasis. J Pediatr Gastroenterol Nutr 2002;34:154-157.

10. Gilbert JD, Scott G, Byard RW. Septo-optic dysplasia and unexpected adult death - an autopsy approach. J Forensic Sci 2001;46:913-915.

11. Barkovich AJ, Norman D. Absence of the septum pellucidum: a useful sign in the diagnosis of congenital brain malformations. AJNR 1988;9:1107-1114.

12. Barkovich AJ, Norman D. MR imaging of schizencephaly. AJNR1988;9:297-302.
13. Skarf B, Hoyt CS. Optic nerve hypoplasia in children: association with anomalies of the endocrine and CNS. Arch Ophthalmol 1984;102:62-67.

14. Thomas PQ, Dattani MT, Brickman JM, et al. Heterozygous HESX1 mutations associated with isolated congenital pituitary hypoplasia and septo-optic dysplasia. Hum Molec Genet 2001;10:39-45.

15. Bennett JL. Developmental neurogenetics and neuro-opthtalmology. J Neuro Ophthalmol 2002;22:286-296.

16. Dattani MT, Martinez-Barbera, JP, Thomas PQ, et al. Mutations in the homeobox gene HESX1/Hesx1 associated with septo-optic dysplasia in human and mouse. Nat Genet 1998;19:125-133.

17. Schuelke M, Krude H, Finckh B, et al. Septo-optic dysplasia associated with a new mitochondrial cytochrome $b$ mutation. Ann Neurol 2002;51:388-392.

18. Sener RN Septo-optic dysplasia associated with cerebral cortical dysplasia (cortico-setpo-optic dysplasia). J Neuroradiol 1996;23:245-247.

19. Senol U, Karaali K, Aktekin B, et al. Dizygotic twins with schizencephaly and focal cortical dysplasia. AJNR 2000;21:1520-1521.

20. Amaral JG, Yanaga RH, Geissler HJ, et al. Schizencephaly: report of eleven cases. Arq Neuropsiquiatr 2001;59:244-249.

21. Barkovich AJ, Kjos BO. Schizencephaly: correlation of clinical findings with MR characteristics. AJNR 1992;13:85-94.

22. Barkovich AJ, Kuznieccky RI, Dobyns WB, et al. A classification scheme for malformations of cortical development. Neuropediatrics 1996;27:59-63. 